\title{
Mercury pollution for marine environment at Farwa Island, Libya
}

\author{
Adel A.S. Banana', R. M. S. Radin Mohamed ${ }^{2}$ and A. A. S. Al-Gheethi ${ }^{2,3^{*}}$
}

\begin{abstract}
Background: Farwa is an Island in Libya receives petrochemical wastes generated from General Company of Chemical Industries (GCCl) since more than 40 years.

Aim: The present work aimed to determine the concentrations of mercury $\left(\mathrm{Hg}^{+2}\right)$ in fish, marine plants and sediment collected from Farwa lagoon to evaluate effect of industrial wastewater from GCCl on the marine environment.

Methods: Hundred and twelve samples of fish, pearl oyster, cuttlefish sediments and marine plants were analyzed to determine $\mathrm{Hg}^{2+}$ concentration during the period from January to August 2014 by using Atomic Absorption Spectrometer (AAS).

Results: The highest concentration of $\mathrm{Hg}^{2+}$ was detected in Pinctada radiata $\left(11.67 \pm 3.30 \mathrm{\mu gg}^{-1}\right)$ followed by Serranus scriba $\left(6.37 \pm 0.11 \mathrm{\mu g} \mathrm{g}^{-1}\right)$ and Epinephelus marginatus $\left(6.19 \pm 0.02 \mu \mathrm{g} \mathrm{g}^{-1}\right)$. About $75 \%$ of marine plants contained the maximum contaminations during the summer season. In fish samples $\mathrm{Hg}^{2+}$ concentrations exceeded the levels provided by international standards.
\end{abstract}

Conclusions: The fish at Farwa lagoon is heavily contaminated with $\mathrm{Hg}^{2+}$ which may represent a source for mercury poisoning for human.

Keywords: Mercury, Fishes, Contamination, Farwa Island

\section{Background}

The increasing of industrial activities has led to increase the contamination of environment with several types of pollutants as due to discharge of industrial wastewater into the environment and aquatic system. petrochemicals factors is among various of industrials process which produce heavily contaminated wastewater. In the developed countries the wastewater are treated using advanced technologies such as reverse osmosis, nanotube carbon, adsorption process using different types of adsorbents as well as photo-degradation processes of degradable toxic compounds. Those technologies have high efficiency to remove most toxic substances from wastewater before final disposal into the environment. Others technologies such as multi-walled carbon nanotube/tungsten oxide (MWCNT/ $\mathrm{WO}_{3}$ ) and alumina nano-particles polyamide membrane

\footnotetext{
* Correspondence: adelalghithi@gmail.com

${ }^{2}$ Faculty of Civil \& Environment Engineering, UTHM, Parit Raja, Malaysia

${ }^{3}$ High Institute of health sciences, Sana'a, Yemen

Full list of author information is available at the end of the article
}

still under investigation and they exhibited high efficiency for the removal and degrade various types of pollutants based on the lab scale experiments [1-7].

In the term of heavy metals contamination, the petrochemical industries represent one of the main sources for generation of these toxics into the environment. the adsorption process materials is the most common treatment process to remove heavy metals from wastewater. Recently, some authors focused on improvement this process to be high efficiency. Gupta et al. [8] has combined the magnetic properties of iron oxide with adsorption properties of carbon nanotubes to increase the removal of $\mathrm{Cr}^{2+}$ ions.

Heavy metals are groups of elements with high molecular weights that are not degraded when taken into the body; instead, they accumulate in specific body organs and cause illness. Heavy metals have the potential to disrupt the metabolism and biological activities of many proteins because it can oxidize the sulfhydryl groups [9]. Among several of heavy metals, mercury $\left(\mathrm{Hg}^{2+}\right)$ is the most toxic 
element for organisms [10-12]. $\mathrm{Hg}^{2+}$ is very toxic pollutant that contaminates fish around the world, therefore fish represent the main source of $\mathrm{Hg}^{2+}$ for human [13]. The studies indicated that mercury accumulation in the oceans correlates with the rising tide of mercury pollution. The most serious $\mathrm{Hg}^{2+}$ poisoning has been occurred due to consumption of $\mathrm{Hg}^{2+}$ contaminated fish and other seafood polluted by industrial wastewater [14]. However, information for mercury contamination of fishes and marine environment in Libya is unavailable; this might due to absence of academic research for more than 40 years. Therefore, the present work aimed to evaluate the concentrations of $\mathrm{Hg}^{2+}$ in fish, sea woods and sediments at Farwa Island, Libya that received petrochemical wastes generated from General Company of Chemical Industries (GCCI) for more than 40 years.

\section{Methods}

\section{Study area}

Farwa Island is located on the Mediterranean in West Zawya, Libya ( $33^{\circ} 04^{\prime} \mathrm{N}, 1^{\circ} 50^{\prime} \mathrm{E}$ to $33^{\circ} 08^{\prime} \mathrm{N}$ and $11^{\circ} 32^{\prime} \mathrm{E}$ ) from Abu- Kamash east to the Tunisian border in the west (Fig. 1). It comprises Farwa lagoon that covering an area of $32 \mathrm{~km}^{2}$ and is the largest lagoon on the Libyan coast. GCCI is located at Abu- Kamash chemical complex. GCCI was opened in 1970s and consist of 3 units that produce 104,000 tonnes/year Ethylene di-chloride, 60, 000 tonnes poly vinyl chloride (PVC), 50,000 tonnes caustic soda and 45,000 tonnes chlorine. In addition to sodium carbonate, sodium hypochlorite and $\mathrm{HCl}$. GCCI has four dumping sites, two of them are located on the west while another two are located on the east.

\section{Collection and analysis of samples}

Hundred ninety two samples (in triplicate, 3 sample/ month) of fishes, oysters, cuttlefish, magnoliophyta plants and sediments were collected from marine environment around of Farwa Island, Libya during the period from January to August 2014. The marine organisms collected samples included ten types of fishes, only one type of oyster and one type of cuttlefish. These samples were collected using local fishermen. Magnoliophyta plant samples were collected from different location around Farwa Lagoon, Zone I (100 m), Zone II (1000 m) and Zone III $(3000 \mathrm{~m})$. These locations represent the distance between the sampling point and the factory and they were selected because its very close to GCCI and the possibility to heavy contamination with $\mathrm{Hg}^{2+}$ is high. The samples were transported inside ice box to the laboratory and kept in deep freezer at $-20{ }^{\circ} \mathrm{C}$ until analysis.

Sample preparation and analysis were carried out according to Bernhard [15]. Liver, muscle, gill, heart, air sac and stomach-intestine were removed before the analysis [16]. Fish samples were homogenized in a blender. Magnoliophyta plants were cut out into small pieces ( $5 \mathrm{~mm}$ in diameter) and then homogenized in a blender. A weight of $10 \mathrm{~g}$ of homogenate for each of fish and magnoliophyta plants was digested according to APHA [17]. In briefly; five $\mathrm{mL}$ of $\mathrm{HNO}_{3}(65 \%)$ and $5 \mathrm{~mL}$ of $\mathrm{H}_{2} \mathrm{SO}_{4}$ were added into sample placed inside flask $(100 \mathrm{~mL})$. The mixture was heated on a hot plate $\left(70-80{ }^{\circ} \mathrm{C}\right)$ for $30 \mathrm{~min}$ to the lowest volume $(20 \mathrm{~mL})$ before precipitation occurs. The digestion step was continued until light colored, clear solution was observed. The flask walls was washed with distilled water and filtered using Whatman, $125 \mathrm{~mm} \varnothing$, filter papers (Cat No. 1001 England). The filtrate was

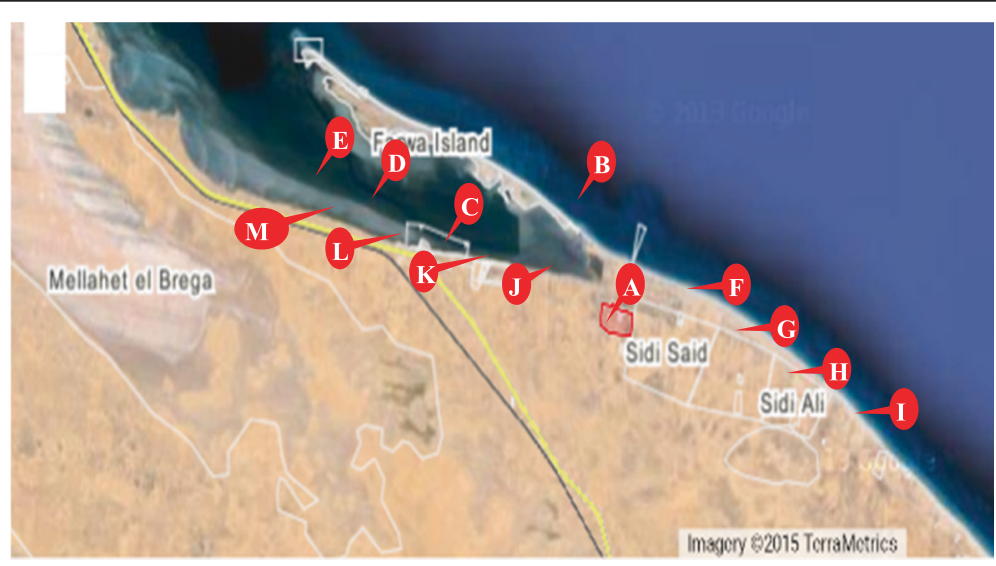

Fig. 1 Google map of study area, A) GCCI B) site of fish samples collection C) site of marine plant samples collection (100 m); D) site of marine plant samples collection (1000 m); E) site of marine plant samples collection (3000 m); F) site of sediment samples collection (100 m, W); G) site of sediment samples collection (500 m, W); H) site of sediment samples collection (1000 m, W); I) site of sediment samples collection (3000 m, W); J) site of sediment samples collection (100 m, E); K) site of sediment samples collection (500 m, E); L) site of sediment samples collection (1000 m, E); site of sediment samples collection (3000 m, E) 
transported into a volumetric flask $(100 \mathrm{~mL})$ with $10 \mathrm{~mL}$ water and mixed thoroughly.

Sediment samples $(1 \mathrm{~kg})$ were collected by using grab sampler from eight sites located on the west and east of GCCI. Samples were transported to the laboratory and dried in oven at $50{ }^{\circ} \mathrm{C}$. After that, sediment samples were powdered and passed through $160 \mu \mathrm{m}$ sieve. The samples packed in paper bags and stored in deep freezer at $-20{ }^{\circ} \mathrm{C}$ prior to analysis. The mercury was extracted from the samples with $10 \mathrm{~mL} \mathrm{HNO}_{3} / \mathrm{HCl}(1: 3 \mathrm{v} / \mathrm{v})$ by using a microwave digestion system as described above.

The $\mathrm{Hg}^{2+}$ concentrations in the digested samples were determined by an atomic absorption spectrophotometer (AAS) (Model P.E.A ANALYST 100, HGA-800 and MHS-10, Perkin Elmer, USA).

Table 1 ANOVA Analysis of $\mathrm{Hg}^{2+}$ concentrations in different fish samples during the period of study from January to August 2014

\begin{tabular}{|c|c|c|c|c|c|c|}
\hline Sample & & Sum of Squares & $\mathrm{df}$ & Mean Square & $\mathrm{F}$ & Sig. \\
\hline \multirow[t]{3}{*}{ Serranus scriba } & Between groups & 54.369 & 7 & 7.767 & 1257.814 & .000 \\
\hline & Within groups & .099 & 16 & .006 & & \\
\hline & Total & 54.468 & 23 & & & \\
\hline \multirow[t]{3}{*}{ Oedalechilus labeo } & Between groups & 28.478 & 7 & 4.068 & 2697.193 & .000 \\
\hline & Within groups & .024 & 16 & .002 & & \\
\hline & Total & 28.502 & 23 & & & \\
\hline \multirow[t]{3}{*}{ Diplodus vulgaris } & Between groups & 6.588 & 7 & .941 & 1146.640 & .000 \\
\hline & Within groups & .013 & 16 & .001 & & \\
\hline & Total & 6.602 & 23 & & & \\
\hline \multirow[t]{3}{*}{ Dicentrarchus labrax } & Between groups & 4.697 & 7 & .671 & 712.616 & .000 \\
\hline & Within groups & .015 & 16 & .001 & & \\
\hline & Total & 4.712 & 23 & & & \\
\hline \multirow[t]{3}{*}{ Lithognathus mormyrus } & Between groups & 70.353 & 7 & 10.050 & 2138.378 & .000 \\
\hline & Within groups & .075 & 16 & .005 & & \\
\hline & Total & 70.428 & 23 & & & \\
\hline \multirow[t]{3}{*}{ Epinephelus marginatus } & Between groups & 99.308 & 7 & 14.187 & 16690.375 & .000 \\
\hline & Within groups & .014 & 16 & .001 & & \\
\hline & Total & 99.321 & 23 & & & \\
\hline \multirow[t]{3}{*}{ Sarpa salpa } & Between groups & 11.577 & 7 & 1.654 & 301.838 & .000 \\
\hline & Within groups & .088 & 16 & .005 & & \\
\hline & Total & 11.664 & 23 & & & \\
\hline \multirow[t]{3}{*}{ Sciaena umbra } & Between groups & 3.448 & 7 & .493 & 467.260 & .000 \\
\hline & Within groups & .017 & 16 & .001 & & \\
\hline & Total & 3.465 & 23 & & & \\
\hline \multirow[t]{3}{*}{ Pagrus pagrus } & Between groups & 3.373 & 7 & .482 & 98.591 & .000 \\
\hline & Within groups & .078 & 16 & .005 & & \\
\hline & Total & 3.451 & 23 & & & \\
\hline \multirow[t]{3}{*}{ Caranx crysos } & Between groups & 5.237 & 7 & .748 & 949.947 & .000 \\
\hline & Within groups & .013 & 16 & .001 & & \\
\hline & Total & 5.249 & 23 & & & \\
\hline \multirow[t]{3}{*}{ Pinctada radiata } & Between groups & 310.444 & 7 & 44.349 & 6809.846 & .000 \\
\hline & Within groups & .104 & 16 & .007 & & \\
\hline & Total & 310.548 & 23 & & & \\
\hline \multirow[t]{3}{*}{ Sepia officinalis } & Between groups & 2.703 & 7 & .386 & 639.161 & .000 \\
\hline & Within groups & .010 & 16 & .001 & & \\
\hline & Total & 2.713 & 23 & & & \\
\hline
\end{tabular}


The concentrations of heavy metals was calculated $\left(\mu \mathrm{g} \mathrm{g}^{-1}\right)$ using Eqs. (1)

$$
\text { MetalConcentration }=A \times B / C
$$

Where

$A=$ concentrations of metals in digested solution $\mu \mathrm{g} \mathrm{g}^{-1}$

$B=$ final volume of digested solution $m L$

$C=$ sample size, gram

\section{Data analysis}

The data were not normally distributed, therefore, they were $\log$ transformed and subjected to parametric statistics. The differences in $\mathrm{Hg}^{2+}$ concentrations of samples investigated were tested by ANOVA. The statistical analyses was performed SPSS (version 11.5).

\section{Results and discussion}

The present study investigated the mercury contamination of marine environment included fishes, oysters, cuttlefish, magnoliophyta plants and sediments at Farwa Island, Libya that are received industrial wastewater generated from GCCI since 40 years ago. The concentration of mercury at this place has not reported before, thus the current work was conducted to evaluate the effect of petrochemical wastewater on the environment. The results revealed that the $\mathrm{Hg}^{2+}$ concentration differed significantly $(\mathrm{p}<0.05)$ during the period of study (Table 1$)$. These variables may be due to the climatic conditions of the area, winter season extends from November to March and is generally cold and rainy with unstable winds blowing from different directions which lead to cause dilution of Farwa lagoon, while summer season (May to September) is rather hot and dry [18]. The mean of $\mathrm{Hg}^{2+}$ concentrations in fish, oysters and cuttlefish samples collected during the period study are presented in Table 2. It can be noted that the $\mathrm{Hg}^{2+}$ concentrations ranged from $3.13 \pm 1.5 \mu \mathrm{g} \mathrm{g}^{-1}$ in Serranus

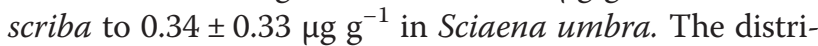
butions of $\mathrm{Hg}^{2+}$ concentrations for each species in the period from January to August 2014 are depicted in Fig. 2. It shown that the highest concentration of $\mathrm{Hg}^{2+}$ was detected in Pinctada radiata $\left(11.67 \pm 3.30 \mu \mathrm{gg}^{-1}\right)$ in August, followed by Serranus scriba $\left(6.37 \pm 0.11 \mu \mathrm{g} \mathrm{g}^{-1}\right)$ in July and Epinephelus marginatus $\left(6.19 \pm 0.02 \mu \mathrm{g} \mathrm{g}^{-1}\right)$ in February. The Serranus scriba have high concentration of $\mathrm{Hg}^{2+}$ during the study period from January to July followed by Epinephelus marginatus, the average was 2.83 vs. $2.18 \mu \mathrm{g}$ g-1. The lowest $\mathrm{Hg}^{2+}$ concentrations were detected in Pagrus pagrus $\left(0.001 \mu \mathrm{g} \mathrm{g}^{-1}\right)$ and Sciaena umbra $\left(0.01 \mu \mathrm{g} \mathrm{g}^{-1}\right)$. Both types contained the lowest average concentrations during the period of study (0.33 and $0.36 \mu \mathrm{g} \mathrm{g}^{-1}$ respectively). Lithognathus mormyrus has the highest $\mathrm{Hg}\left(3.59 \pm 0.19 \mu \mathrm{g} \mathrm{g}{ }^{-1}\right)$ among the fish samples collected in April, whereas Oedalechilus labeo has the highest $\mathrm{Hg}\left(3.59 \pm 0.01 \mu \mathrm{g} \mathrm{g}^{-1}\right)$ among the fish samples collected in May. In June, the highest $\mathrm{Hg}^{2+}$ was determined in Lithognathus mormyrus $\left(4.97 \pm 0.04 \mu \mathrm{g} \mathrm{g}^{-1}\right)$.

The analysis for association between $\mathrm{Hg}^{2+}$ concentrations in fish, oysters as well as cuttlefish samples and months indicated that the concentration of $\mathrm{Hg}^{2+}$ in Serranus scriba, Dicentrarchus labrax, Sciaena umbra and Pinctada radiata associated significantly $(p<0.05)$ to the seasons with $\mathrm{R}^{2} 0.64,0.24,0.21$ and 0.34 respectively (Table 3). The $\mathrm{Hg}^{2+}$ concentrations in magnoliophyta plants are presented in Table 4 . It can be noted that the maximum concentration was detected in the samples

Table $2 \mathrm{Hg}^{2+}$ concentrations in Fishes collected from Farwa lagoon, Libya which received petrochemical wastes from General Company of Chemical Industries (GCCl), $( \pm$ SD represent the standard division from the mean, $n=24$ for each sample)

\begin{tabular}{|c|c|c|c|c|}
\hline Sample No. & Family name & English name & Science name & Hg concentration $\left(\mu \mathrm{g} \mathrm{g}^{-1}\right)$ \\
\hline 1 & Serranidae & Painted comber & Serranus scriba & $3.13 \pm 1.5$ \\
\hline 2 & Mugilidae & Boxlip Mullet & Oedalechilus labeo & $1.4 \pm 1.1$ \\
\hline 3 & Sparidae & Common Two-Banded Seabream & Diplodus vulgaris & $1.4 \pm 0.53$ \\
\hline 4 & Moronidae & European seabass & Dicentrarchus labrax & $0.89 \pm 0.45$ \\
\hline 5 & Sparidae & Striped sea bream & Lithognathus mormyrus & $1.5 \pm 0.7$ \\
\hline 6 & Serranidae & Dusky Grouper & Epinephelus marginatus & $1.9 \pm 2.0$ \\
\hline 7 & Sparidae & Salema & Sarpa salpa & $0.99 \pm 0.71$ \\
\hline 8 & Sciaenidae & sculpin & Sciaena umbra & $0.34 \pm 0.33$ \\
\hline 9 & Dentex macrophthalmus & Red porgy & Pagrus pagrus & $0.39 \pm 0.38$ \\
\hline 10 & Carangidae & blue runner & Caranx crysos & $0.78 \pm 0.48$ \\
\hline 11 & Oyster & Rayed Pearl Oyster & Pinctada radiata & $2.3 \pm 3.6$ \\
\hline 12 & Cuttlefish & common cuttlefish & Sepia officinalis & $0.63 \pm 0.34$ \\
\hline
\end{tabular}




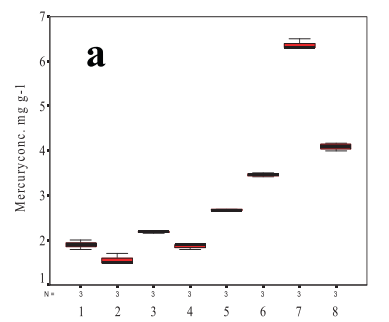

Month

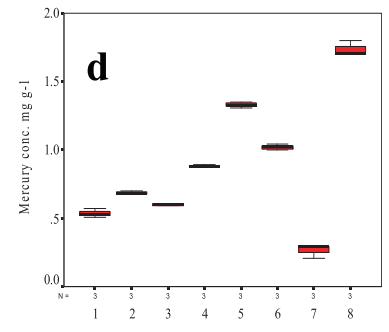

Month

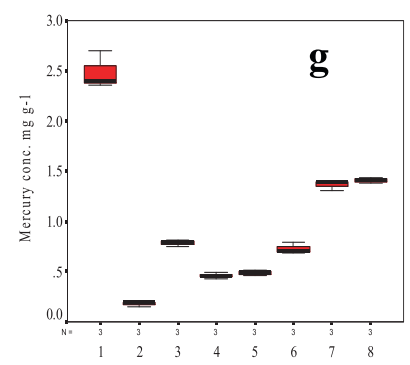

Month

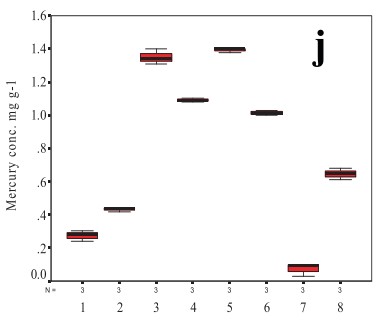

Month

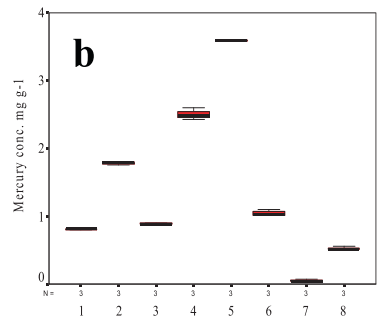

Month

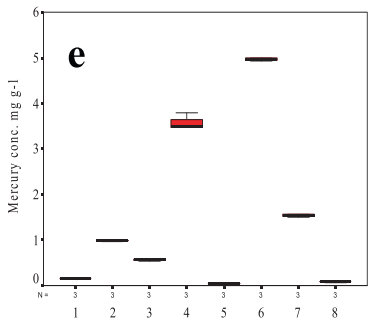

Month

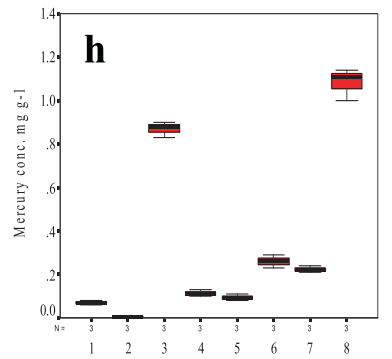

Month

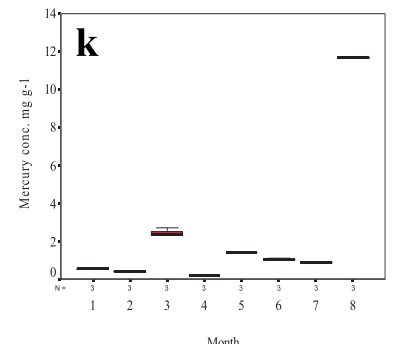

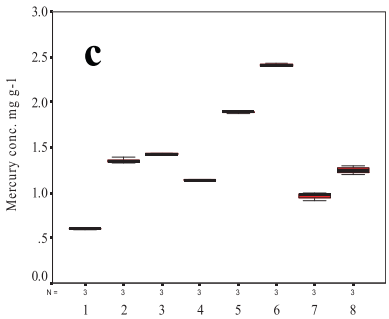

Month

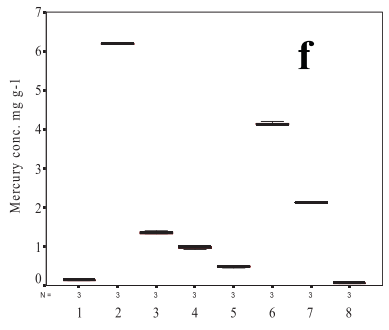

Month

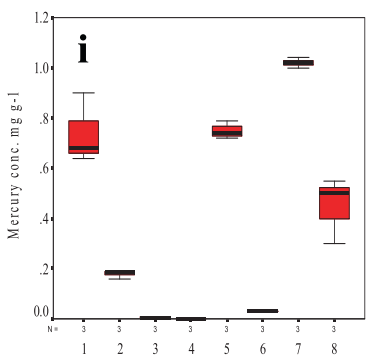

Month

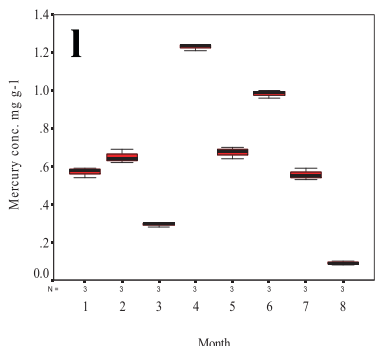

Fig. 2 Seasonal distribution of $\mathrm{Hg}^{2+}$ concentrations in fish, oysters and cuttlefish samples collected from Farwa lagoon, Libya; a) Serranus scriba; b) Oedalechilus labeo, c) Diplodus vulgaris; d) Dicentrarchus labrax; e) Lithognathus mormyrus; f) Epinephelus marginatus; g) Sarpa salpa; h) Sciaena umbra; i) Pagrus pagrus; j) Caranx crysos; k) Pinctada radiate; I) Sepia officinalis

collected from place near of GCCI $(100 \mathrm{~m})$. The highest concentrations were determined in samples collected during April, where, $2.33 \pm 0.60,1.44 \pm 0.42$ and $0.96 \pm 0.12 \mu \mathrm{g} \mathrm{g} \mathrm{g}^{-1}$ were determined in samples collected from zone I, II and III respectively. The lowest $\mathrm{Hg}^{2+}$ was recorded in samples collected from zone III $\left(0.02 \pm 0.00 \mu \mathrm{g} \mathrm{g}^{-1}\right)$ during January. In comparison with the study conducted by Pergent-Martini [19] which was carried out on the mercury contamination in the Posidonia oceanica Collected from mediterranean sea.
It can be noted that the $\mathrm{Hg}^{2+}$ concentrations in this study was quite high. There would be due to dispose of wastewater generated from GCCI into the sea without treatment process since 40 years ago.

The present study revealed that the concentrations of $\mathrm{Hg}^{2+}$ in all types of fish samples were more than the standards limits recommended by FDA and FAO-WHO [20, 21]. According to U.S. EPA [22], $\mathrm{Hg}^{2+}$ should be less than $0.3 \mu \mathrm{g} \mathrm{g}^{-1}$ wet fish muscle tissue for protection of human health. However, Zaza et al. [13] reported that 
Table 3 Measures of association between $\mathrm{Hg}^{2+}$ concentrations in fish, oysters as well as cuttlefish samples and months

\begin{tabular}{lccccc}
\hline Sample*month & $R$ & R Squared & Eta & Eta Squared & Significance $(p$ value $)$ \\
\hline Serranus scriba & 0.80 & 0.64 & 0.99 & 0.99 & 0.01 \\
Oedalechilus labeo & -0.228 & 0.05 & 1.00 & 0.99 & 0.14 \\
Diplodus vulgaris & 0.327 & 0.11 & 0.99 & 0.99 & 0.06 \\
Dicentrarchus labrax & 0.493 & 0.24 & 0.99 & 0.99 & 0.01 \\
Lithognathus mormyrus & 0.191 & 0.04 & 0.99 & 0.99 & 0.18 \\
Epinephelus marginatus & -0.173 & 0.03 & 1.00 & 0.00 & 0.21 \\
Sarpa salpa & -0.068 & 0.01 & 0.99 & 0.99 & 0.99 \\
Sciaena umbra & 0.454 & 0.21 & 0.99 & 0.98 & 0.01 \\
Pagrus pagrus & 0.215 & 0.05 & 0.98 & 0.99 & 0.16 \\
Caranx crysos & 0.006 & 0.00 & 0.99 & 1.00 & 0.45 \\
Pinctada radiata & 0.587 & 0.34 & 1.00 & 0.99 & 0.01 \\
Sepia officinalis & -0.188 & 0.04 & 0.99 & \\
\hline
\end{tabular}

the minimum level of $\mathrm{Hg}^{2+}$ is $0.5 \mu \mathrm{g} \mathrm{g}^{-1}$ for fish species. In the present study, the minimum concentration of $\mathrm{Hg}^{2+}$ was $1 \mu \mathrm{g} \mathrm{g}{ }^{-1}$ in Pagrus pagrus. Fish consumption is one of the major factors of $\mathrm{Hg}^{2+}$ intake for humans $[23,24] . \mathrm{Hg}^{2+}$ is very dangerous for pregnant woman because mercury is most harmful to developing foetuses, infants, and young children.

High $\mathrm{Hg}^{2+}$ concentration was detected in sediment samples collected from the West of GCCI than those collected from the East. However, both sites contain high concentration of $\mathrm{Hg}^{2+}$. The $\mathrm{Hg}^{2+}$ concentration decreased significantly $(p<0.05)$ as the site distance from GCCI, the maximum $\mathrm{Hg}^{2+}$ was noted in sediment samples taken from the west (100 $\mathrm{m}$ from GCCI) where 11.14 \pm $4.11 \mu^{-1} \mathrm{~g}^{-1}$ was recorded in April 2014 (Table 5). Among the sediment samples collected from the east, the samples

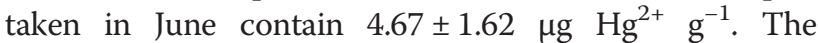

Table $4 \mathrm{Hg}^{2+}$ concentrations in magnoliophyta plant samples collected from different distance of GCCl at Farwa lagoon, Libya ( \pm SD represent the standard division from the mean, $n=3$ for each sample per month)

\begin{tabular}{lccc}
\hline Sample/month & \multicolumn{3}{c}{$\mathrm{Hg}^{2+}$ concentrations $\left(\mathrm{Hg} \mathrm{g}^{-1}\right)$} \\
\cline { 2 - 4 } & Zone I (100 m) & Zone II $(1000 \mathrm{~m})$ & Zone III (3000 m) \\
\hline 1 & $0.82 \pm 0.20$ & $0.93 \pm 0.13$ & $0.02 \pm 0.00$ \\
2 & $0.39 \pm 0.12$ & $0.50 \pm 0.08$ & $0.10 \pm 0.09$ \\
3 & $2.10 \pm 0.91$ & $0.57 \pm 0.16$ & $0.82 \pm 0.20$ \\
4 & $2.33 \pm 0.60$ & $1.44 \pm 0.42$ & $0.96 \pm 0.12$ \\
5 & $1.06 \pm 0.18$ & $0.79 \pm 0.12$ & $0.75 \pm 0.19$ \\
6 & $1.00 \pm 0.13$ & $1.38 \pm 0.92$ & $0.54 \pm 0.20$ \\
7 & $0.87 \pm 0.30$ & $0.25 \pm 0.09$ & $0.64 \pm 0.21$ \\
8 & $1.40 \pm 0.42$ & $1.07 \pm 0.13$ & $0.71 \pm 0.15$ \\
\hline
\end{tabular}

pollution of environmental area around GCCI represent a serious problem due to that the surrounding areas are used for agricultural purpose such as for Grapes, olives and almonds. More than 1500 people are living around the GCCI.

Farwa Island has high fishery production, but this Island had been exposed for heavy pollution due to GCCI for more than 40 years. Farwa Island is the most important coastal and marine site in western Libya, in terms of its high marine and coastal biodiversity based on several surveys and studies during the last years. However, no information was recorded according to mercury pollution. This region is characterized by an exceptional importance in terms of fish and artisanal fisheries, aquaculture, sea birds, sea grass meadows, land/seascape features and, above all, as one of the few regions in the Mediterranean to experience active tidal movements. In addition to some endangered species which makes it an important area for larva and juvenile protection. In the term of biodiversity, Farwa has many economically important species and certain endangered species are recognized [18].

In the term of toxic pollutants in industrial wastewater and their environmental impact and health effect, the sea water around of GCCI should be treated to remove of $\mathrm{Hg}^{2+}$ ions. Variety of biological and physico-chemical methods for wastewater treatment has been developed. Among those technologies, reverse osmosis, activated carbon, advanced oxidation, alumina-coated carbon nanotubes, tire derived carbons, porous carbon, carbon nanotubes and fullerene and $\mathrm{CNT} /$ magnesium oxide composite have exhibited high efficiency for removal of heavy metals from different aqueous solution [25-33]. 
Table $5 \mathrm{Hg}^{2+}$ concentrations in sediment samples collected from the west and east GCCl during the period January to August 2014 ( \pm SD represent the standard division from the mean, $n=3$ for each sample per month)

\begin{tabular}{|c|c|c|c|c|c|c|c|c|c|}
\hline \multirow{3}{*}{$\begin{array}{l}\text { Sediments } \\
\text { sample/month }\end{array}$} & \multicolumn{9}{|c|}{$\mathrm{Hg}^{2+}$ Concentration $\left(\mu \mathrm{g} \mathrm{g}^{-1}\right.$ ) } \\
\hline & \multicolumn{4}{|l|}{ West of GCCl } & \multicolumn{4}{|l|}{ East of GCCl } & \multirow{2}{*}{$\begin{array}{l}\text { Control } \\
\text { Zwara city }(20 \mathrm{~km}\end{array}$} \\
\hline & $<100 m$ & $500 \mathrm{~m}$ & $1000 \mathrm{~m}$ & $3000 \mathrm{~m}$ & $100 \mathrm{~m}$ & $500 \mathrm{~m}$ & $1000 \mathrm{~m}$ & $3000 \mathrm{~m}$ & \\
\hline 1 & $3.54 \pm 1.10$ & $1.38 \pm 0.14$ & $1.09 \pm 0.04$ & $0.64 \pm 0.32$ & $1.96 \pm 1.01$ & $0.55 \pm 0.06$ & $0.03 \pm 0.0$ & $0.01 \pm 0.0$ & $0.001 \pm 0.0$ \\
\hline 2 & $6.74 \pm 3.14$ & $4.06 \pm 1.81$ & $1.07 \pm 0.52$ & $0.32 \pm 0.19$ & $1.55 \pm 0.71$ & $1.12 \pm 0.24$ & $0.75 \pm 0.18$ & $0.01 \pm 0.0$ & $0.001 \pm 0.0$ \\
\hline 3 & $4.58 \pm 1.43$ & $3.04 \pm 0.93$ & $0.06 \pm 0.09$ & $0.02 \pm 0.01$ & $2.07 \pm 0.91$ & $0.75 \pm 0.18$ & $0.05 \pm 0.01$ & $0.001 \pm 0.0$ & $0.001 \pm 0.0$ \\
\hline 4 & $11.14 \pm 4.11$ & $2.64 \pm 0.83$ & $1.95 \pm 0.31$ & $0.56 \pm 0.08$ & $3.65 \pm 1.04$ & $1.47 \pm 0.91$ & $0.01 \pm 0.0$ & $0.001 \pm 0.0$ & $0.001 \pm 0.0$ \\
\hline 5 & $8.50 \pm 2.84$ & $5.07 \pm 2.81$ & $1.01 \pm 0.41$ & $0.75 \pm 0.11$ & $3.12 \pm 1.11$ & $0.06 \pm 0.01$ & $0.003 \pm 0.0$ & $0.001 \pm 0.0$ & $0.001 \pm 0.0$ \\
\hline 6 & $2.46 \pm 1.31$ & $3.65 \pm 1.71$ & $0.95 \pm 0.71$ & $0.07 \pm 0.22$ & $4.67 \pm 1.62$ & $1.5 \pm 0.46$ & $0.001 \pm 0.0$ & $0.01 \pm 0.0$ & $0.003 \pm 0.0$ \\
\hline 7 & $5.21 \pm 2.28$ & $4.06 \pm 1.93$ & $0.50 \pm 0.01$ & $0.43 \pm 0.17$ & $2.13 \pm 0.98$ & $0.04 \pm 0.0$ & $0.01 \pm 0.0$ & $0.002 \pm 0.0$ & $0.001 \pm 0.0$ \\
\hline 8 & $1.56 \pm 0.73$ & $3.25 \pm 0.88$ & $0.36 \pm 0.03$ & $0.05 \pm 0.0$ & $3.17 \pm 0.51$ & $1.45 \pm 0.29$ & $0.003 \pm 0.0$ & $0.002 \pm 0.0$ & $0.001 \pm 0.0$ \\
\hline
\end{tabular}

\section{Conclusions}

It can be concluded that the heavily contamination of fish, oysters as well as cuttlefish in marine environment around GCCI represent a main source for food poisoning among peoples living in this area. Therefore, the contaminated area should be treated to prevent health risk associated with mercury contamination.

\section{Competing interests}

The authors declared that they have no competing interest.

\section{Authors' contributions}

AA, RMS and AAS: conceived and planned the experiment. AA collected the samples and carried out the experiment. AAS: formulated the objectives, analysed the data, and drafted the manuscript. RMS has proofread and edited the Manuscript, provided guidance and improved the quality of the final manuscript. All authors read and approved the final manuscript. (AAB, RMSRM and A-GAAS).

\section{Acknowledgments}

The authors would like to thank Badu Society for Protection Marine Biology and Wild for allow us to use their laboratories. In addition, to express their appreciations to the Universiti Tun Hussein Onn Malaysia (UTHM), School of Civil and Environmental Engineering for Postdoctoral Fellowship to Adel Al-Gheethi.

\section{Author details}

${ }^{1}$ Environment Engineering Department, Subrata College, University of Zawia, Zawia, Libya. ${ }^{2}$ Faculty of Civil \& Environment Engineering, UTHM, Parit Raja, Malaysia. ${ }^{3}$ High Institute of health sciences, Sana'a, Yemen.

\section{Received: 6 May 2015 Accepted: 15 February 2016}

\section{Published online: 20 February 2016}

\section{References}

1. Mittal A, Kaur D, Malviya A, Mittal J, Gupta VK. Adsorption studies on the removal of coloring agent phenol red from wastewater using waste materials as adsorbents. J Coll Interface Sci. 2009;337:345-54.

2. Mittal A, Mittal J, Malviya A, Kaur D, Gupta VK. Decoloration treatment of a hazardous triarylmethane dye, Light Green SF (Yellowish) by waste material adsorbents. J Coll Interface Sci. 2010;342:518-27.

3. Mittal A, Mittal J, Malviya A, Gupta VK. Removal and recovery of Chrysoidine $Y$ from aqueous solutions by waste materials. J Coll Interface Sci. 2010;344:497-507.

4. SaleH TA, Gupta VK. Functionalization of tungsten oxide into MWCNT and its application for sunlight-induced degradation of rhodamine B. J Coll Interface Sci. 2010;362:337-44.

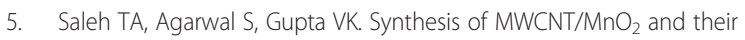
application for simultaneous oxidation of arsenite and sorption of arsenate. Appl Catal B Environ. 2011;106:46-53.

6. Saleh TA, Gupta VK. Synthesis and characterization of alumina nano-particles polyamide membrane with enhanced flux rejection performance. Sep Pur Technol. 2012:89:245-51.

7. Vinod K, Gupa VK, Jain R, Nayak A, Agarwal S, Shrivastava M. Removal of the hazardous dye-Tartrazine by photodegradation on titanium dioxide surface. Mat Sci Eng: C. 2011;31:1062-7.

8. Gupta VK, Nayak A. Cadmium removal and recovery from aqueous solutions by novel adsorbents prepared from orange peel and $\mathrm{Fe}_{2} \mathrm{O}_{3}$ nanoparticles. Chem Eng J. 2012;180:81-90.

9. Gupta VK, Agarwal S, Saleh TA. Chromium removal by combining the magnetic properties of iron oxide with adsorption properties of carbon nanotubes. Water Res. 2011:45:2207-12.

10. Epstein E: Health issues related to beneficial use of biosolids. In: 16th Annual Residuals and Biosolids Management Conference of the Water Environment Federation, Texas. 2002, p. 9.

11. Clarkson TW. The toxicology of mercury. Crit Rev Clin Lab Sci. 1997;34:369-403.

12. Magos L. Physiology and toxicology of mercury. Metal lons Biol Sys. 1997;34:321-70

13. Langford N, Ferner R. Toxicity of mercury. J Hum Hypertens. 1999;13(10): 651-6.

14. Zaza S, de Balogh K, Palmery M, Pastorelli AA, Stacchini P. Human exposure in Italy to lead, cadmium and mercury through fish and seafood product consumption from Eastern Central Atlantic Fishing Area. J Food Comp Anal 2015, (Accepted). doi: 10.1016/j.jfca.2015.01.007.

15. Harada M. Minamata disease: methylmercury poisoning in Japan caused by environmental pollution. Crit Rev Toxicol. 1995;25:1-24.

16. Bernhard M. Manual of methods in aquatic environment research, part 3: sampling and analyses of biological material. Rome: FAO Fish Tech Paper No. 158, UNEP; 1976.

17. Öztürk M, Özözen G, Minareci O, Minareci E. Determination of heavy metals in fish, water and sediments of Avsar dam lake in Turkey, Iran. J Environ Health Sci Eng. 2009;6(2):73-80

18. APHA. Standard methods for the examination of water and wastewater. 20th ed. Washington, DC: American Public Health Association; 1998.

19. Haddoud DA, Rawag AA. Marine protected areas along Libyan coast; In Report of the MedSudMed expert consultation on marine protected areas and fisheries management. MedSudMed Technical Documents No. 3 Rome (Italy), June 2007 GCP/RER/010/ITA/MSM-TD-03. 2007.

20. Pergent-Martini C. Posidonia oceanica: a biological indicator of past and present mercury contamination in the mediterranean sea. Marine Environ Res. 1998:45:101-11.

21. Hall RA, Zook EG, Meaburn GM. National Marine Fisheries Service. Survey of trace elements in the fishery resource. U.S. Department of Commerce National Oceanic and Atmospheric Administration National Marine Fisheries Service. 1978.

22. Voegborlo RB, Methnani AME, Abedin MZ. Mercury, cadmium and lead content of canned Tuna fish. Food Chem. 1999;67(4):341-5. 
23. EPA US. Water quality criterion for the protection of human healthmethylmercury. Office of Science and Technology, Office of Water, USEPA: U.S. Environmental Protection Agency; 2001.

24. Santos ECO, Camara VM, Jesus IM, Brabo ES, Loureiro ECB, Mascarenhas AFS, Fayal KF, Sa Filho GC, Sagica FES, Lima MO, Higuchi H, Silveira IM. A contribution to the establishment of reference values for total mercury levels in hair and fish in Amazonia. Environ Res. 2002;90:6-11.

25. Yasutake A, Matsumoto M, Yamaguchi M, Hachiya N. Current hair mercury levels in Japanese: survey in five districts. Tohoku J Exper Med. 2003;199:161-9.

26. Gupta VK VK, Srivastava SK, Mohan D, Sharma S. Design parameters for fixed bed reactors of activated carbon developed from fertilizer waste for the removal of some heavy metal ions. Waste Manag. 1997;17:517-22.

27. Gupta VK, Agarwal S, Saleh TA. Synthesis and characterization of aluminacoated carbon nanotubes and their application for lead removal. J Hazar Mat. 2011;185:17-23.

28. Saleh TA, Gupta VK. Photo-catalyzed degradation of hazardous dye methyl orange by use of acomposite catalyst consisting of multi-walled carbon nanotubes and titanium dioxide. J Colloid Interface Sci. 2012;371:101-6.

29. Saleh TA, Gupta VK. Processing methods, characteristics and adsorption behavior of tire derived carbons: A review. Adv Colloid Interface Sci. 2014;211:93-101.

30. Gupta VK, Kumar R, Nayak A, Saleh TA, Barakat MA. Adsorptive removal of dyes from aqueous solution onto carbon nanotubes: A review. Adv Colloid Interface Sci. 2013;193-194:24-34.

31. Gupta VK, Ali A, Saleh TA, Nayak A, Agarwal S. Chemical treatment technologies for waste-water recycling —an overview. RSC Adv. 2012;2:6380-8.

32. Gupta VK, Saleh TA. Sorption of pollutants by porous carbon, carbon nanotubes and fullerene- An overview. Environ Sci Poll Res. 2013;20:2828-43.

33. Saleh TA, Gupta VK. Column with CNT/magnesium oxide composite for lead(II) removal from water. Environ Sci Pollut Res Int. 2012;19:1224-8.

\section{Submit your next manuscript to BioMed Central and we will help you at every step:}

- We accept pre-submission inquiries

- Our selector tool helps you to find the most relevant journal

- We provide round the clock customer support

- Convenient online submission

- Thorough peer review

- Inclusion in PubMed and all major indexing services

- Maximum visibility for your research

Submit your manuscript at wuw biomedcentral.com/submit

) Biomed Central 